\title{
SCENES FROM THE COMEDY
}

Prologue I

ACT ONE: Laughter at the Gods in Classical Times 9

1. Old Comedy in Aristophanes' Hands I6

2. Lucretius on the Unholy Nature of Things 32

3. Laughter Overheard by Cicero $4 \mathrm{I}$

4. Lucian Laughing Outright 55

ACT TWO: Humanist Games in Christian Times 65

1. Erasmus's Praise of Folly 70

2. Montaigne's Que sais-je? 88

3. Hobbes's Braving of the Dark 98

4. Spinoza's Deification of the Whole Lot Io8

5. Bayle's Send-up of a Comet I23

6. Hume's Jesting with Natural Religion 139

7. Whose Aberglaube? I55

ACT THREE: Laughter at the Passing Generations I69

1. New Comedy in the Hands of Plautus and Shakespeare 177

2. Unfailing Impersonations by Molière 200

3. Adaptation of the Tragicomedy by Novelists 216

4. Jesus vs. God in Saramago's Novel 230

Notes 249

Index 26I 
This page intentionally left blank 
THE HUMANIST COMEDY 
This page intentionally left blank 